\title{
POST OCCUPANCY EVALUATION (POE): A TOOL TO INVESTIGATE THE RESIDENTS' SATISFACTION AND PERFORMANCE OF HOUSING PROJECT, CASE STUDY - KANHAPUR, INDIA
}

\author{
Dr. Anamika Jiwane $1 ه$ \\ ${ }^{1}$ Department of Architecture and Interior Design, University of Bahrain, Bahrain.
}

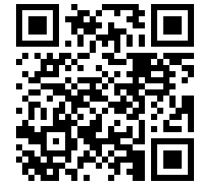

Received 01 September 2021

Accepted 20 September 2021

Published 31 October 2021

\section{CorrespondingAuthor}

Dr Anamika Jiwane, ajiwane@uob.edu.bh DOI 10.29121/ijetmr.v8.i10.2021.1041

Funding: This research received no specific grant from any funding agency in the public, commercial, or not-for-profit sectors.

Copyright: (C) 2021 The Author(s). This is an open access article distributed under the terms of the Creative Commons Attribution License, which permits unrestricted use, distribution, and reproduction in any medium, provided the original author and source are credited.

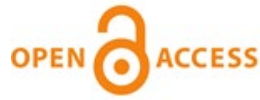

\section{ABSTRACT}

In developing countries like India, very less research has been conducted on the Post Occupancy Evaluation (POE) of rural housing projects. This research aims to investigate the performance of an Eco-Village at Kanhapur, India which was designed by the Centre of Science for Villages. Research investigation was based on the occupants' views on the physical condition of their housing units and neighborhood spaces. The study aided to determine the occupants' housing satisfaction and thus evaluate the housing quality in the rural housing projects. The results revealed that, CSV, failed in achieving the residential satisfaction and the model of Eco-village collapsed. The housing project could offer them the shelter, but not the livable conditions on account of multiple reasons discussed in the paper. CSV never came back to the community to take the feedback on their living conditions and problems even after 10 years of occupancy. The study of this eco village led to the conclusion that POE can be utilized as a powerful tool to diagnose the residential satisfaction and thereby investigate the loopholes in the performance of housing projects.

Keywords: Post-Occupancy Evaluation, Occupants' Satisfaction, Housing Quality Indicators, Residential Satisfaction Factors, Sustainable Planning, Participation

\section{INTRODUTION}

Houses are one of the basic human needs. They need to be designed to satisfy their needs of habitation. Generally, these are designed by the architects based upon the predictions of satisfaction and hence common observation is that, there is a wide gap between the design intent and the final performance of the house after occupation (Loftness et al. (2009). This may be because the occupants' view is never taken into consideration as an important data that should be analyzed by the architects during the design of such houses (Southworth and Cranz (2012). Post Occupancy evaluation is a process that allows a systematic study of housing from the perspective of the occupants once they start living in them. Lessons from such study can bring huge scope for improvement and direct the future designs of housing projects (Watson (2003)).

This research is basically based on the major concern in developing countries like India, where the dwellers are neither consulted for participation nor they are heard for their true needs in Rural housing projects. Generally, the architects and housing agencies do not turn back to evaluate the satisfaction of the occupants after they occupy the housing project. This affects the process of understanding the developing needs of the 
occupants and thereby affect their residential satisfaction.

\section{Objectives of the study}

- To discuss various parameters of residential satisfaction in a rural housing project, India

- To determine the role of POE as an essential tool to take feedback from the dwellers on their satisfaction for dwelling units and environment.

- To investigate the importance of POE in evaluating the performance of projects.

Significance of study: Results of this study will be beneficial to the housing authorities and organizations Government/ Non-Government across the nation:

They will realize the urgency to study the current and future needs of the project occupants with their participation.

They will be able to enlist the factors that affect the satisfaction and dissatisfaction of the dwellers

Results of the study will formulate lessons for the other developers in housing sector to direct the performance of their projects.

Research questions: Author's concern for studying the performance of rural housing project, created a series of research questions for investigation:

- Why is it important to study the performance of rural housing project?

- How is the residential satisfaction of the occupants and the performance of housing projects correlated?

- What are the factors that contribute to the occupants' residential satisfaction?

- How to conduct POE in rural housing projects and who should be responsible for conducting POE?

The findings of the study will portray the importance and relevance of POE to sustainable public housing development especially in developing countries like India. Therefore, the use of POE has become necessary to identify areas of weakness and guide future developments in public housing development.

\section{THEORETICAL FRAMEWORK}

Housing is a primary universal concern because it is essential for all the countries to make sure that its people are living with an acceptable living standard. This living standard is highly connected to their own residential satisfaction. Residential and neighborhood satisfactions are important indicators of housing quality and condition which affect individuals' quality of life (Idrus and Ho (2008). POE has emerged as a strategic performance measurement tool that is able to examine the performance of housing project after the houses are handed over to the occupants. Therefore, it is important to study the concept of residential satisfaction, its major components, process of post occupancy evaluation, its benefits, different theories that explain those aspects and finally the impact of POE on determining the performance of housing project.

\subsection{POST OCCUPANCY EVALUATION (POE)}

Post occupancy evaluation is a procedure for determining whether the design decisions made by the Architect/ Planner are delivering the performance value that 
is needed by the occupants? By using the occupants as a benchmark in the evaluation, POE provides enormous potential for improving the performance of a housing project. POE can be evolved to fill the gaps in the conventional building and design process, which primarily consists of planning, programming, design, construction and occupancy of dwellings. POE is a systematic manner of evaluating houses after they have been built and occupied for a certain duration of time (Preiser,1995, 2002). This can ensure that occupants' comments are not biased or superficial, but are genuine remarks on their own built environment. Once the houses have been occupied for some time, the occupants get accustomed and adjusted to the new space and the experience of moving does not bias the results (Huizenga et al. (2003).

Occupants when participate in POE, can provide information and feedback to the architects, designers and the involved housing agencies; this can benefit them to find out the mistakes in their design to avoid such in future projects. Thus, the occupants can be made to participate in their housing research and contribute valuable information to ensure that the housing as an end-product meets their demands and needs. Government as the highest decision-making authority in the developing countries can be benefitted by the feedback of the occupants to rephrase their housing policy framework.

POE consists of collecting information in several forms, including community profile data, occupant's satisfaction data and interviews with key design construction and operation personnel (Carmody (2002). POE uses direct experiences of occupants of an environment as the fundamental principle to evaluate the intended use of a living place (Darkwa (2006); because occupants can provide the first-hand information from their experiences.

There are many benefits of post-occupancy evaluation (POE). By understanding how housing supports or hinders the living of occupants; their houses can be tailored to meet their needs. POE can help to measure the ways people can use their houses efficiently and cost-effectively. POE can detect non-functional or never used areas inside and outside the houses for future corrections (Darkwa (2006). (Presiser et al. (1988), classifies short-term, medium-term and long-term benefits of POE. These discuss the success and failure of the housing projects as well as benefits in terms of achieving cost effectiveness, functionality, maintenance, management, and above all the occupants' satisfaction. Better results of POE can be obtained with its deeper investigation. The participants should be given prior understanding on the benefits they would receive after their participation in the POE process; to enhance its effectivity.

Occupants' opinions on their living comfort values are noted and recorded during POE. POE aims at identifying the lacunae to improve upon the housing planning and designing to perform well for the users. It helps to make sure that users find their houses livable and comfortable. Livability is a capacity of a residential space to meet the daily living needs of a family/household through its design, arrangement and construction (Beamishand Day (1988). Generally, Livability is defined by the professionals in a different way and perceived by the dwellers in different way.

\subsection{RESIDENTIAL SATISFACTION}

Researches and data available on residential satisfaction show that the residential satisfaction is a multidimensional phenomenon which encompasses 
physical and social qualities of house and its neighborhood. It can be defined in simple words as a response by the dwellers to their living environment. Residential satisfaction is basically a reflection of degree to which the inhabitants feel that their housing is helping them to achieve their goals. This includes the measurement of conditions of built environment by individual dweller as per his/her needs and aspirations. According to Salles (2008), theories on residential satisfaction are based on the notion that residential satisfaction is a measure of the difference between occupants' actual housing and their desired housing and neighborhood situations. Housing Needs Theory, Housing deficit theory and Physiological Construct theory are used to explain the residential satisfaction. Housing Needs Theory is framed on the idea of discrepancy between current needs and desired needs of individuals (Rossi, 1955, in Mohit and Raja (2014). Housing deficit Theory revolves around the point that individuals judge their housing conditions on the available norms (Morris and winter, 1978). Physiological construct theory is based on the fact that individuals create a reference condition and compare their situation to it (Galster,1985 in Mohit and Raja (2014).

Almost all researchers in housing including Onibokun (1974), believe that the housing satisfaction is composed of satisfaction with dwelling unit and the neighborhood as well. Factors related to housing unit are its structural quality, age, materials, occupancy period, cost etc. whereas neighborhood factors are about its location, safety, approachability, access to facilities, sociocultural background etc. Dwellers' personal characteristics that contribute to their satisfaction include household size, age group, income range, ownership, last place of residence, time period of occupancy, education, job type, cultural background etc.

Level of satisfaction depends upon occupant's perceived ideas on personal and social life and when this level is not achieved, there are 3 possibilities. They reconsider their needs or improve their housing condition or plan to shift to another location. Reference can be taken to Morris and Winter (1978) casual model of Residential satisfaction which is also called as Housing Adjustment theory to measure the causes, consequences and process of satisfaction/ Dissatisfaction. Sometimes, It is difficult to measure the dynamic reaction between the dwellers an their environment because it is contributed by both subjective and objective attributes. The objective attributes relate to their environment- the physical space itself whereas the subjective attributes relate to psychological aspects and the personal characteristics (Wish (1986). Housing evaluation is a multi-disciplinary activity based on many theories and concepts. There is no one method or formula of measurement and the researchers have to use approaches suitable to the situation. Who interacts with what, when and how; shape the nature of the occupants' experience. Quantification of occupants' experience is inevitably difficult, as it measures who interacts with the house, how, when and where (Kasim et al. (2014).

\section{RESEARCH METHODOLOGY}

Research was conducted as a case study in a small village called Kanhapur, Maharashtra, India. The total number of houses in the community is 25 . The dwelling units spread on a rectangular plot of approximately one and half acres [ Ref Figure 1]. Total 24 families live in this community which make up a population of 124 members including 56 males and 68 females. The occupants were shelter less in the past, identified as 'the most needy' by Center of Science for villages (CSV) and the dwelling units at Kanhapur were offered to them for living as free. These units 
were constructed as 'Pucca' by using vernacular materials and low cost techniques called 'Wardha techniques' invented by CSV, India.

POE of housing requires to answer' what' 'how' and 'why' type of questions to measure their performance. A combination of multiple data collection methods was employed to answer the 'what' 'why' and 'how' questions. The methods included onsite observations, Attitude Test Battery and household surveys to achieve both the qualitative and quantitative data. Few key informants like the head of the village, CSV authorities, Contactor of the project were contacted for supportive information. The methodology was directed to receive data regarding 1 . Occupants' view on the physical condition of the dwelling units, comparative study of conditions of houses since allocation 2. Occupants' overall housing satisfaction.

Several researches have been performed till now with an objective of establishing the hypothesis that there is a relationship between the satisfaction of the user and the physical conditions of the built environment. Ample literature is available on housing evaluation using occupants' satisfaction indicators in housing performance evaluation. Some of these are by Jiboye (2012); Ilesanmi (2010) etc. They argue about the conventional methods of asking the users about their satisfaction levels because they believe that the answers are too broad and do not help in measuring the effective performance of housing in developing countries. This could be on account of various attributes that affect their responses as satisfied, very satisfied and not satisfied. Hence the author has used surveys to collect data from dwellers and conducted onsite detailed observations to increase the reliability of data.

Architects are generally blamed for being trained to be inclined in more interpretive work. Hence, a research outlook is needed which can adequately describe the qualities of the interaction between people and their physical environment. Built environment needs to be interpreted as a symbol of cultural values and social orders of its inhabitants. This means there cannot be a generalized model and one will be required to understand the subjective experience of individual and view unique events as keys to useful insights.

The research was majorly based on receiving firsthand information by using a combination of onsite observations, Attitude Test Battery and Household surveys etc. Few informal discussions with key informants were done to support the information. Most of the data collected was of qualitative type so the analysis was situational and subjective. Author managed to conduct Household surveys for all 24 houses. Observations onsite were very important; notes were recorded regarding the occupants' daily activities both personal and social. Drawings and sketches were drawn in addition to the photographic evidences. Attitude Test Battery was conducted for few participants to seek an idea about their attitude and understanding towards their environment. It aimed at studying the attitude of respondents towards various sustainable techniques offered by CSV for their development and effectiveness of such project in terms of satisfaction and knowledge base of beneficiaries regarding the different schemes. They were being questioned about the consequences of various development activities in terms of overall changes brought with reference to social cohesion, economic development, environmental issues, basic needs of water and sanitation etc. The author wanted to study the perception of the respondent about his personal gain / loss as a result of various developmental activities initiated by CSV or Government and also pertaining to the basic aspect of their lifestyle. 


\section{FINDINGS AND DISCUSSION}

\subsection{HOUSEHOLD SURVEY}

All the families belonged to EWS (economically weaker section) mostly engaged in agricultural labor activities with no optional opportunities of income during the non-agricultural months. Majority of the villagers were educated up to Primary School education. Lack of higher education seemed to be an obstacle in coping up with sustainable measures given by the planners. $85 \%$ households had average 5 members. Provision of one-room dwelling was found non-sufficient to accommodate their needs. Hence, $80 \%$ households constructed extensions to their allocated houses. About $60 \%$ of them showed the extension as large as $50 \%$ in addition to their original construction.

Low level of awareness and high level of ignorance were observed to be the two major reasons for the failure of sustainability practices implemented by CSV. CSV involved the community in planning but only as labors during construction stage. All the houses looked identical inside and outside.

$50 \%$ occupants admitted to have rainwater harvesting tanks but only $10 \%$ used it regularly. Bio-fuel stove was found to be used by only $2 \mathrm{HH}$. Rest complained about the stove to be time consuming. The dry garbage was an alternate fuel in stove, and the working women could not manage to spare time in busy mornings. Similar was the story of Bio-gas plant which was initially in working condition for 1-2 years and supplied alternate energy to all $\mathrm{HH}$. But later it stopped working because the villagers did not take efforts to refill the tank with cow dung and instead expected CSV to do thus might it. The aim behind Bio-Gas was to bring the sustainable use of energy in the form of alternate source and save cost on regular electricity. During talks with the key informants, it was highlighted that the occupants receive the electricity with subsidized rate under government schemes for Rural areas and thus might not have cared about alternate sources.

Solar lights were provided on street at two locations, but they were not in use. Occupants admitted that one of the community dwellers had stolen the batteries. Now village is not having any more benefit of solar powered lights. Useful trees were planted by CSV in individual houses as well as in public spaces. They have been taken care and $90 \%$ people accepted that these benefitted them in many ways. The toilets were designed with traps that require least water to run off the waste to save water. These toilets are connected to two soak pits which means that when one pit is full other pit can be used without any problem and the waste in the first pit gets converted into usable manure by the time the second pit gets filled up. The villagers did not show interest in reuse of human waste as manure.

About construction conditions, $45 \%$ of $\mathrm{HH}$ complained of having leakage through roofs, $30 \%$ complained of cracks in walls and floors. $100 \%$ participants agreed that the room constructed for them was very small in size and demanded construction of another room in addition (ref fig 4). They were happy about the size of the plot but about single room dwelling.

\subsection{ONSITE OBSERVATIONS}

Community Plan shows that the houses laid along a major axis in a linear pattern. (Figure 1) The dwelling units were not planned to create cluster which 
could enhance healthy living in rural communities (Charles Correa, 1992). Villagers mostly like to spend time outdoors, socialize more and many of their activities of the day are performed in outdoor spaces with no concern to privacy. The community design did not allow any scope for their indigenous lifestyle. The basic built up area of the housing unit is only in the form of a single room measuring $235 \mathrm{sq}$. $\mathrm{ft}$., hence could not satisfy their daily needs (Figure 6). To meet those needs they had to construct extensions in all possible directions to the existing unit with affordable materials. The materials and techniques used for these extensions did not match with the existing architectural and construction style (ref Figure 2). The reasons for using such materials could be their limited budget as well as lack of training by CSV regarding their Wardha techniques. The extensions to dwelling units crated unpleasing visual patches (Figure 3). Some common spaces were left unused and uncared due to undesired location and size (Figure 4, Figure 5). Onsite observations were found enough to conclude that space planning had errors from occupants' lifestyle point of view. Personal and social spaces could not accommodate the occupants' daily rural routine.

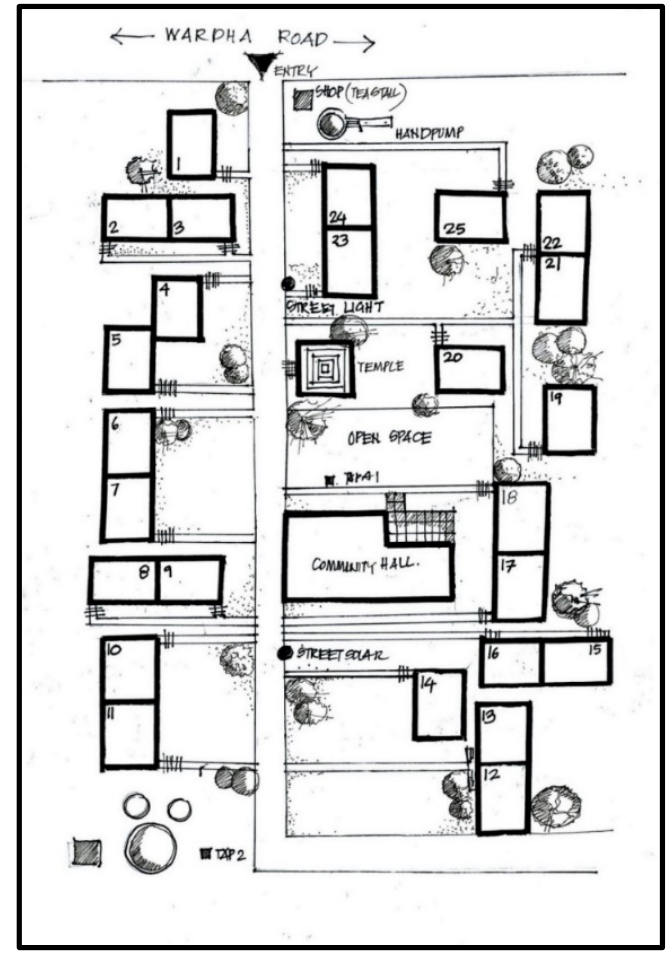

Figure 1 Sketch showing Community Plan at Kanhapur

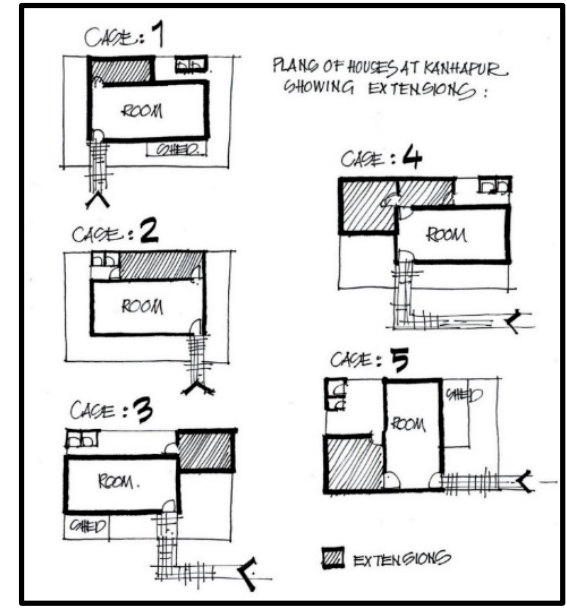

Figure 2 Sketches showing extensions to dwelling units at Kanhapur

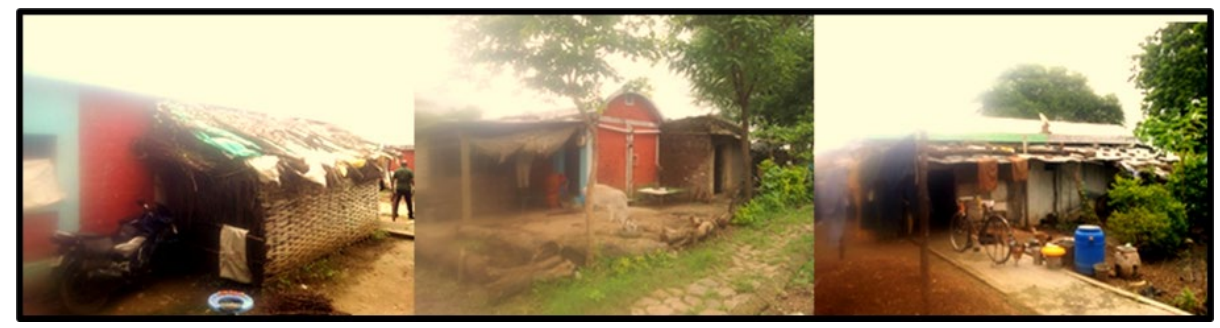

Figure 3 Extensions added to the houses in the community, Kanhapur 


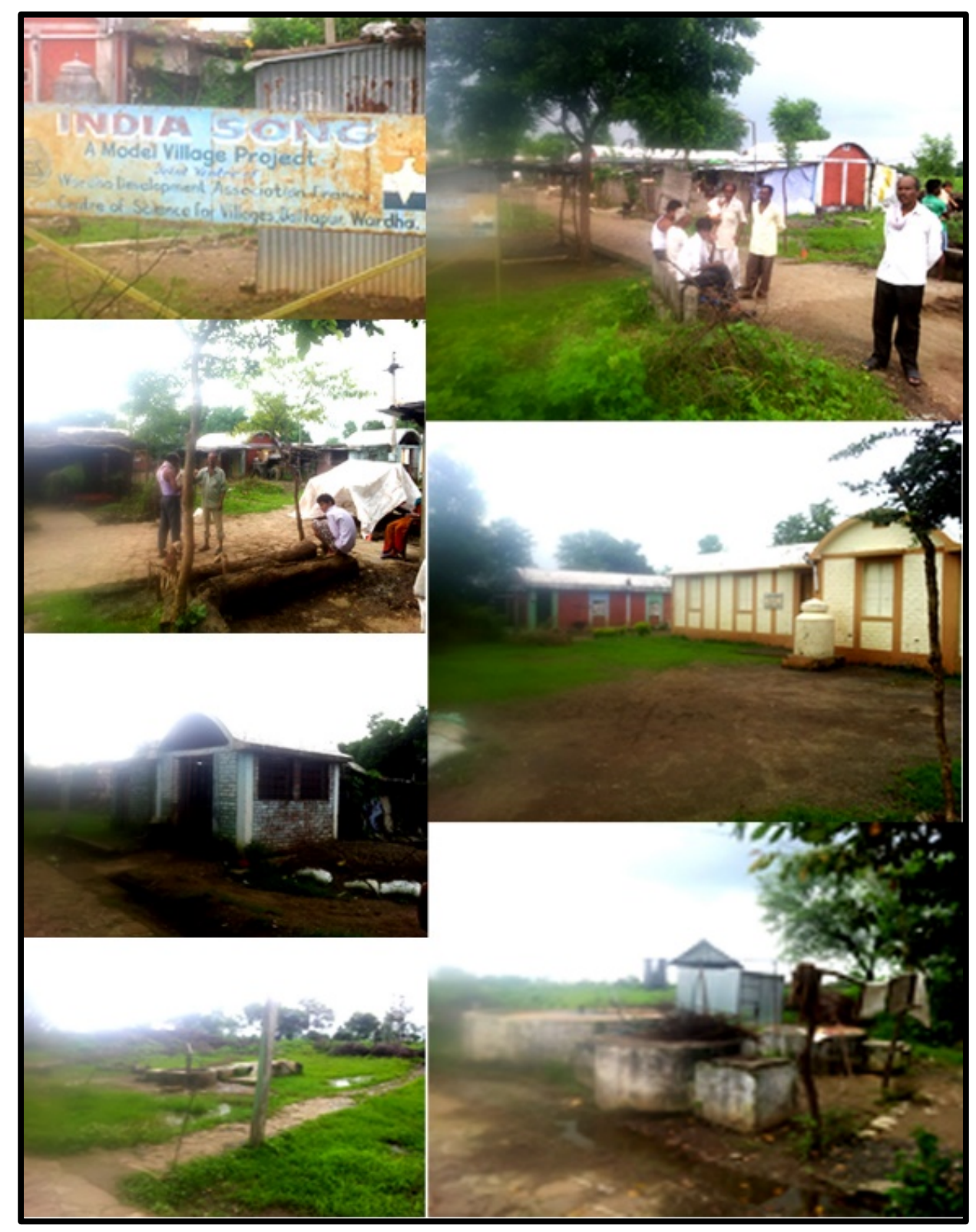

Figure 4 Outdoor spaces in Community, Kanhapur

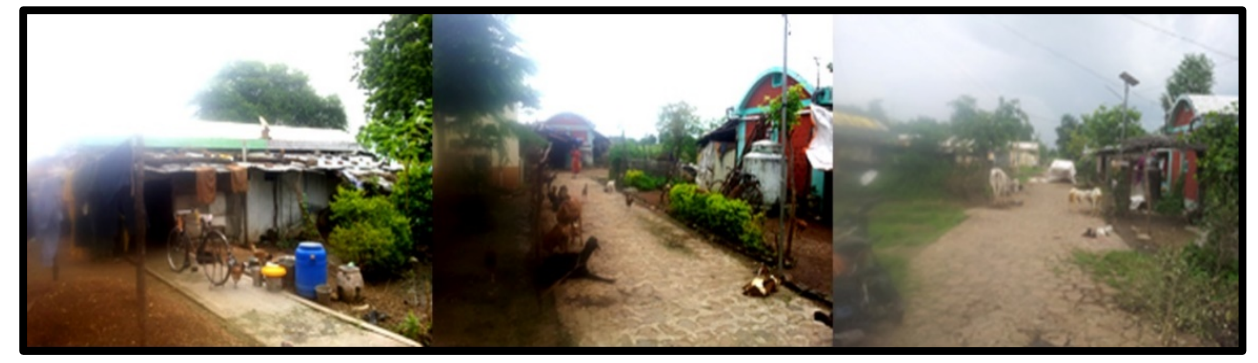

Figure 5 Unplanned spaces in community, Kanhapur 


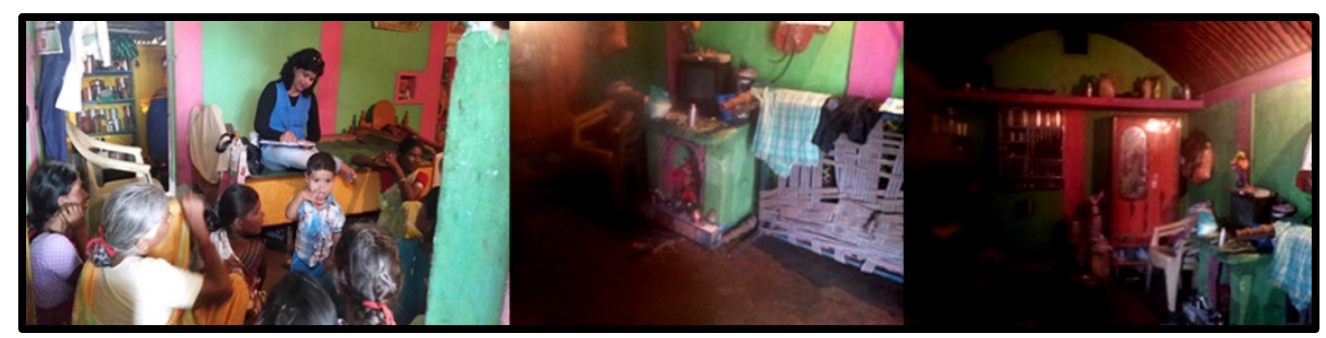

Figure 6 Interior space in Dwelling units, Kanhapur

\subsection{ATTITUDE TEST BATTERY}

The attitude test battery helped to measure the dwellers' know-how about their own environment. Seven (7) occupants participated in the activity; which though was not a large number but enough to help in getting useful information. They showed the knowledge of sustainable tools integrated with community design by the CSV. They admitted the benefits of water supply, sewage disposal, lighting, sanitation, alternate energy sources etc. but blamed CSV for not revisiting the community for any feedback and improvements. Attitude Test Battery had few Value Based questions, which were not fully answered by them. But the filled up information was enough to adjudge their 'recipient' type behavior rather than 'participant' type behavior. They expressed their 'busy daily schedule' as an excuse for non-participation in maintenance of any services.

\subsection{RESIDENTS' OPINION STUDY}

Author prepared a chart (Table 1) to collect the residents' opinions on their living environment. It was divided into 2 parts: a. Characters related to Individual house and 2 . Characters related to neighborhood. The chart was filled by 32 dwellers living in the village. Results showed that all the respondents were happy about the psychological comfort aspect as they were having the ownership over the house. All of them showed strong dissatisfaction on the insufficiency of space for daily domestic usage. They showed their nonsatisfaction on the quality of structure and services. Houses were constructed with Wardha techniques (as mentioned earlier) which uses the local mud material for thermal comfort inside the houses. Occupants showed happiness about it. At neighborhood level, they were satisfied about the provision of various trees, greenery and the roads (within the community). Connectivity of the community to nearby villages was a point of dissatisfaction. All basic services and facilities were provided by CSV to the community, but ignorance towards their maintenance led them to disaster and hence dissatisfaction.

\begin{tabular}{|c|c|c|c|c|c|c|}
\hline \multicolumn{4}{|c|}{ Criteria of evaluation } & \multicolumn{3}{|c|}{ Scale of Grading } \\
\hline Place to be evaluated & Physical CharacteI & & & Good & Average & Bad \\
\hline \multirow{5}{*}{$\begin{array}{l}\text { Characters related to } \\
\text { individual house }\end{array}$} & \multirow{2}{*}{$\begin{array}{l}\text { Quality of visual } \\
\text { appearance }\end{array}$} & Internal & & - & - & 32 \\
\hline & & External & & 2 & 5 & 25 \\
\hline & \multicolumn{2}{|c|}{ Quality of Structure / Maintenance } & & - & 4 & 24 \\
\hline & \multicolumn{3}{|l|}{ Quality of Services } & 3 & 7 & 22 \\
\hline & Quality of comfort & $\begin{array}{l}\text { Physical } \\
\text { (thermal) }\end{array}$ & comfort & 32 & - & - \\
\hline
\end{tabular}




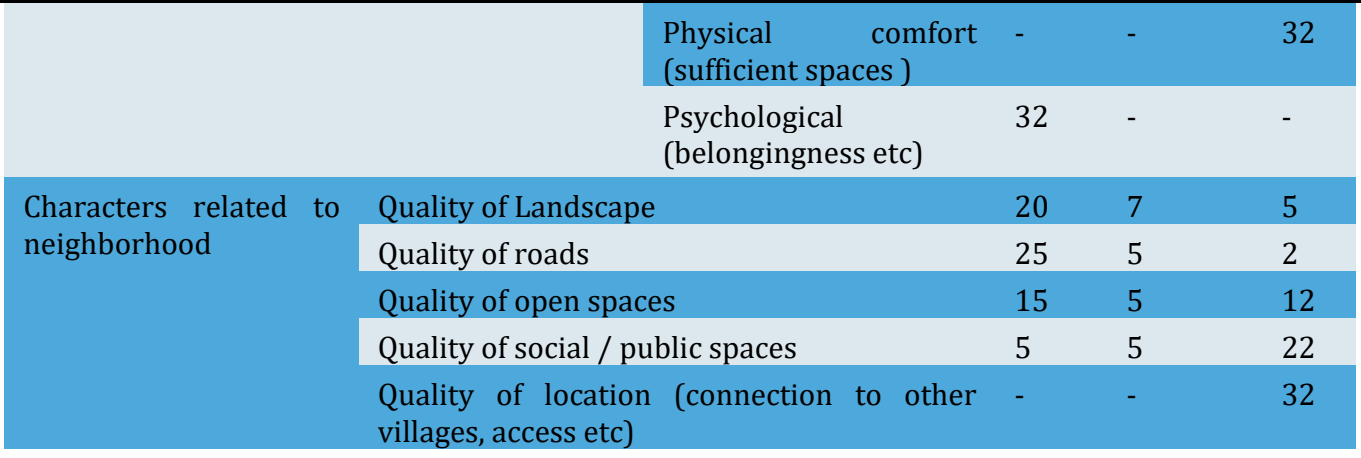

(source-author)

Literature review supports that the post occupancy evaluation study leads to adjudge the success or failure of the performance of houses. It was witnessed during this study. Truly speaking, quality of the built environment is an intangible concept and cannot be easily interpreted by the dwellers and hence the perception on satisfaction gets influenced. Evaluation of the built environment if achieved, can be an indicator of the quality which exists and the potential it affords in achieving a quality its residents would wish to have. However, as an inherent characteristic of every environment, some quality will exist which is related to its opportunity for evolution and growth. "Since the world obviously does not function normally when quality is subtracted, quality exists, whether it is defined or not"( Pirsig in McWatt, (2014). Quality of the built environment is largely an experiential characteristic rather than a physical one and only residents after their stay can comment on this. Following are some of the issues highlighted from the study:

The community dwellers did not have spaces for different types of social gathering and activities on daily basis. The linear arrangement of units did not facilitate their neighborhood interaction. They complained about the lack of social fabric in their community planning. All the occupants were from economically weaker section and hence for them giving time to daily wage work was a priority the time spent for maintenance and community-sustaining activities. CSV is the legal land-owner of Kanhapur eco-village. Occupants were transferred the ownership rights except a right to sale. The eco-village is under the jurisdiction of Kanhapur Gram Panchayat. But the regular conflict between the two, has kept the eco-village disadvantaged over basic amenities by the Gram Panchayat.

Biogas plant and BioFuel stove were seen no more in use by the occupants. Rainwater tanks were found beyond repair and maintenance. Waste disposal system in which the human waste to be translated into useful manure was not mentally accepted by the occupants. Solar street light batteries were stolen. Extensions to the houses were added by using cheap plastic material that is nonrecyclable. Reasons could be summarized as the lack of education and understanding on sustainable planning by the occupants, lack of training to the occupants and lack of time to time visit by CSV the to make sure the performance of sustainable tools of planning. The soil in Kanhapur is black cotton and the plinth for toilet was just at the ground level. Therefore, the rising water level made the toilets underused during rainy season, spreading diseases and embarrassment to the women folk to use outdoor spaces as alternate to the toilets. The walls, floors and ceilings had leakage and seepage problem due to improper quality of construction and lack of maintenance. 
Needs assessment: The goal of Needs Assessments is to help focus a community's efforts on its most critical local housing problems. CSV neither performed Needs assessment and nor did they study the life style of the dwellers. As a result, occupants' current and future needs were not addressed. Some of these needs included sheds for cattle, spaces for growing family etc. They ended up responding to this by constructing extensions. Still the occupants showed satisfaction over the dwellings may be because owning a shelter for a shelter less person [ in past days] is a proud achievement.

Public participation: According to Henry Sanoff (1990 b), process of public participation increases people's awareness of responsibility for decision making. Users can then manage, evaluate maintain and adjust the design of the project to meet changes in their needs. This way the participants feel proud and are always willing to take care and look for it (Wates and Knevitt (1987). At Kanhapur, the dwellers were not consulted in design or planning stages and had no participation in their community design. The planners and designers sitting away from the community site, did not consider their socio-cultural pattern and rural lifestyle. of the occupants and ended up providing identical houses to all. This has impacted the satisfaction of the dwellers over the façade expression of their units which does not distinguish them from each other.

\section{CONCLUSION}

POE study and analysis, indicate signs of failure on the performance of the housing project at Kanhapur. CSV established Kanhapur as a model of eco-village and repeated the same in other locations without realizing the need of any post occupancy evaluation study at Kanhapur. Author highlights the fact that 'Provision of sustainable tools by the providers does not guarantee the formation of eco villages or eco-communities; rather it is the inception, conception and perception of occupants about these sustainable ways of living that make the development sustainable'. The study raises a question mark on the architectural practices in rural regions in developing countries like India, in which the communities are left ignored. Lack of understanding needs of the community has resulted into designing of insufficient, inappropriate, non-flexible and non-suitable spaces. As a reaction, community had to perform alterations and modifications to the original dwellings. If CSV had performed the POE, then the missing gaps in 'the provided and the needed' could be detected and required action could have been taken to sustain the performance of the project. This could formulate a reference study for CSV to refine their ecovillage model and avoid repetition of such mistakes in future projects.

\section{RECOMMENDATIONS}

Author felt that the template used during the Residential satisfaction study at Kanhapur was very brief and may have resulted in surface information. Hence suggests the modified template as shown in table 2 . The template is divided into 4 sections based on the components and determinants of residential satisfaction: sociodemographic characteristics, housing characteristics, neighborhood characteristics and behavioral characteristics (Mohit and raja, 2014) and has scope for detailed POE study. Deeper the POE study, better are the benefits for the architects, Policy makers etc. Also looking into the confusion on indicating satisfaction on services and facilities by the occupants at Kanhapur; author has suggested separate spaces for satisfaction comments on availability of a 
facility/service and quality of that facility/service. In housing project for lower Income Groups, the occupants may be satisfied just for the provision of a facility / service without considering its quality. This may lead to the wrong interpretations during the study.

\begin{tabular}{|c|c|c|}
\hline \multicolumn{3}{|c|}{ Part 1: Socio-demographic characteristics } \\
\hline \multicolumn{2}{|l|}{ Name of the occupant } & $\mathrm{Mr} / \mathrm{Mrs}$ \\
\hline \multicolumn{2}{|l|}{ Age of the occupant } & ____ Years \\
\hline \multicolumn{3}{|l|}{ Educational status } \\
\hline \multicolumn{2}{|l|}{ Income Range } & INR \\
\hline \multicolumn{2}{|l|}{ Tenure status } & Ownership/ Rented \\
\hline \multicolumn{2}{|l|}{ Household size } & ___ members \\
\hline \multicolumn{2}{|l|}{ Years of stay in housing project } & years \\
\hline \multicolumn{2}{|c|}{ Past living experience before shifting to this project } & Good/ Average/ Bad \\
\hline \multicolumn{2}{|l|}{ Reasons for shifting } & Forced/voluntary \\
\hline \multicolumn{2}{|l|}{ If voluntary, explain } & \\
\hline \multicolumn{2}{|c|}{ Community Participation in the current Project } & Yes / No \\
\hline \multicolumn{3}{|l|}{ If yes, describe your role } \\
\hline \multicolumn{3}{|l|}{ Part II: Housing Characteristics } \\
\hline \multicolumn{2}{|l|}{ Physical Characters } & Good Average Bad \\
\hline \multirow[t]{3}{*}{ Quality of visual appearance } & Internal appearance of unit & \\
\hline & External appearance of unit & \\
\hline & Facade expression & \\
\hline \multirow[t]{3}{*}{ Quality of dwelling unit } & Materials and techniques & \\
\hline & Environmental sustainability & \\
\hline & Structure & \\
\hline \multirow[t]{2}{*}{ Quality of management } & Maintenance & \\
\hline & Services to the unit & \\
\hline \multirow[t]{8}{*}{ Quality of comfort (physical) } & Safety /security & \\
\hline & Thermal & \\
\hline & Acoustics & \\
\hline & Access & \\
\hline & View & \\
\hline & Privacy & \\
\hline & Ventilation & \\
\hline & $\begin{array}{l}\text { Sufficiency of spaces } \quad \text { (space } \\
\text { ergonomics) }\end{array}$ & \\
\hline \multirow{2}{*}{$\begin{array}{l}\text { Quality of comfort (psychological } \\
\text { ) }\end{array}$} & Reflection of culture & \\
\hline & Place identity/attachment & \\
\hline
\end{tabular}




\section{Social bonding}

\begin{tabular}{|c|c|c|}
\hline \multirow[t]{2}{*}{ Road network, connectivity } & \multicolumn{2}{|l|}{ Availability } \\
\hline & \multicolumn{2}{|l|}{ Quality } \\
\hline \multirow[t]{2}{*}{ Open, green, social spaces } & \multicolumn{2}{|l|}{ Availability } \\
\hline & \multicolumn{2}{|l|}{ Quality } \\
\hline \multirow{2}{*}{$\begin{array}{l}\text { Location values (nearness to health, } \\
\text { transport, recreation etc) }\end{array}$} & \multicolumn{2}{|l|}{ Availability } \\
\hline & \multicolumn{2}{|l|}{ Quality } \\
\hline \multirow{2}{*}{$\begin{array}{l}\text { Basic amenities (daily needs shop, } \\
\text { bus stop etc) }\end{array}$} & \multicolumn{2}{|l|}{ Availability } \\
\hline & \multicolumn{2}{|l|}{ Quality } \\
\hline \multicolumn{3}{|l|}{ Part IV: Behavioral characteristics } \\
\hline \multicolumn{2}{|c|}{ Have you made any alteration or modification } & YES / NO \\
\hline \multicolumn{3}{|l|}{ If NO, why? } \\
\hline \multicolumn{3}{|l|}{ If YES, explain } \\
\hline \multicolumn{2}{|l|}{ Who did the modification/ alteration } & Self / hired contractor \\
\hline \multicolumn{2}{|c|}{ How do you look upon the housing organization (Govt/ NGO) } & Facilitator/provider \\
\hline \multicolumn{2}{|l|}{ Future intention of mobility } & Yes / No \\
\hline \multicolumn{3}{|l|}{ If No, why } \\
\hline \multicolumn{3}{|l|}{ If Yes, why } \\
\hline
\end{tabular}

(source: author)

To measure the residential satisfaction is a complex process because it is very subjective, relates to a case specific context and hence above suggested model cannot be generalized and needs customization suitable for the chosen location. Multiple data gathering methods in addition to residents' satisfaction survey should be employed to earn a true picture of the performance of any housing project.

\section{REFERENCES}

Beamish, J.0. and Day, S. (1988). Housing Livability: Evaluation by standards, professionals and residents. Housing science 12. 239-250.

Carmody, J. (2002). Post occupancy evaluation of DNR area Office Headquarters at Tower and Windom, Minnesota. Center for Sustainable building research, Minnesota.

Correa, Charles (2014). Blessings of the sky .Available at: $<$ www.charlescorrea.net/pdfs/essay07.pdf > [ accessed 14 April, 2014].

Darkwa, I. (2006). Post occupancy evaluation of state-subsidized housing units in kayamandi, Stellenbosch. Masters in Consumer Science (Housing), University of Stellenbosch. Retrieved from http://scholar.sun.ac.za/handle/10019.1/1642

Huizanga, C., Zagerus, L., rens, E., and Lehreer, D., (2003). Measuring indoor environmental quality: A webbsaded occupant survey. Center for the Built environment, Berkeley, Wurster hall.

Idrus, N., \& Ho, C. S. (2008). Affordable And Quality Housing Through The Low Cost Housing Provision In Malaysia. In Seminar of Sustainable Development and 
Governance, Department of Civil Engineering, and Architecture, Toyohashi University of Technology, 26 June 2008 (pp. 1-21). Retrieved from https://citeseerx.ist.psu.edu/viewdoc/download?doi=10.1.1.865.7533\&re $\mathrm{p}=$ rep1\&type $=$ pdf

Ilesanmi, Adetokunbo Oluwole, (2010). Post-occupancy evaluation and residents' satisfaction with public housing in Lagos, Nigeria. Journal of Building Appraisal.Vol.6, pp153-169. Retrieved from https://doi.org/10.1057/jba.2010.20

Jiboye A.D., (2012). Post-occupancy evaluation of residential satisfaction in Lagos, Nigeria: Feedback for residential improvement. Frontiers of Architectural Research. Volume 1, Issue 3, September 2012, pp 236-243. Retrieved from https://doi.org/10.1016/j.foar.2012.08.001

Kasim, R., Ishiyaku, B. and Harir, A.I. (2014). Performance criteria for public housing evaluation in developing countries (Case Study of Gombe Metropolis, Nigeria). Available at: Retrieved from https://pdfs.semanticscholar.org/5933/bf05bc8609cd2bf10e3497864c99 e83d7d8a.pdf

Loftness, V., Aziz, A., Choi, J., Kampschroer, K., Powell, K., Atkinson, M., \& Heerwagen, J. (2009). The value of post-occupancy evaluation for building occupants and facility managers. Intelligent Buildings International, 1(4), 249- 268. doi:10.3763/inbi.2009.SI04 Retrieved from https://doi.org/10.3763/inbi.2009.SI04

McWatt, A.M. (2014). A Critical Analysis of Robert Pirsig's Metaphysics of Quality. Available at: Retrieved from https://cdn.websiteeditor.net/90e0cb600d8146f9af85b88f0c2f8fb2/files/uploaded/A.McWat t-PhD\%2520Thesis\%2520June\%25202011\%2520pp.pdf

Mohit, M.A. and Raja, K.A.M.M. (2014). Residential satisfaction- concept, theories and empirical studies. Planning Malaysia: urban Planning and Local Governance. Vol. III (2014), pp. 47-66. Retrieved from https://doi.org/10.21837/pmjournal.v12.i3.131

Morris, E.W. and Winter, M.(1978). Housing, family and society. New York: John Wiley and sons.

Salleh, A.G., (2008). Neighborhood factors in private low-cost housing in Malysia, 32. Habitat international. 485-493. Retrieved from https://doi.org/10.1016/j.habitatint.2008.01.002

Preiser, WF., Rabinowitz, HZ, and White, ET., (1988) Pot occupancy evaluation. New York. Van Nostrand Rreinhold.

Sanoff, H., (1990). Participatory Design, Theory and Techniques. North Carolina: Book Masters.

Southworth, M., \& Cranz, G. (2012). People in the Design of Urban Places. Journal of Urban Design, 17(4),461-465. Retrieved from http://www.tandfonline.com/doi/abs/10.1080/13574809.2012.720757

Wates N, Knevitt C., (1987). Community architecture: How people are creating their own environment. London: Penguin Books.

Watson, C. (2003). Review of Building quality using post-occupancy evaluation. Journal of Program Educational Buildings. 35:1-5. 
Wish, N.B. (1986). Are we really measuring quality of life? American Journal of economics and Sociology, 45(10), Pp 93-99 Retrieved from https://doi.org/10.1111/j.1536-7150.1986.tb01906.x 